Research article

\title{
Molecular characterisation of Mycobacterium tuberculosis isolates in the First National Survey of Anti-tuberculosis Drug Resistance from Venezuela
}

\author{
Liselotte Aristimuño ${ }^{1,3}$, Raimond Armengol ${ }^{2}$, Alberto Cebollada3 , \\ Mercedes España ${ }^{2}$, Alexis Guilarte ${ }^{2}$, Carmen Lafoz ${ }^{3}$, María A Lezcano ${ }^{4}$, \\ María J Revillo4, Carlos Martín ${ }^{3}$, Carmen Ramírez², Nalin Rastogi ${ }^{5}$, \\ Janet Rojas ${ }^{2}$, Albina Vázques de Salas ${ }^{2}$, Christophe Sola ${ }^{5}$ and Sofía Samper*4
}

\begin{abstract}
Address: ${ }^{1}$ Escuela de Medicina, Universidad Centroccidental Lisandro Alvarado, Venezuela, ${ }^{2}$ Programa Nacional Integrado de Control de la Tuberculosis, MSDS, Venezuela, ${ }^{3}$ Grupo de Genética de Micobacterias, Departamento de Microbiología, Medicina Preventiva y Salud Pública, Universidad de Zaragoza, España, ${ }^{4}$ Servicio de Microbiología, Hospital Universitario Miguel Servet, Zaragoza, España and ${ }^{5}$ Unité de la Tuberculose et des Mycobactéries, Institut Pasteur, Pointe-à-Pitre, Guadeloupe

Email: Liselotte Aristimuño - lisearistimuno@yahoo.es; Raimond Armengol - programatbvenezuela@yahoo.com; Alberto Cebollada - alberto@unizar.es; Mercedes España - programatbvenezuela@yahoo.com;

Alexis Guilarte - programatbvenezuela@yahoo.com; Carmen Lafoz - clafoz@unizar.es; María A Lezcano - malezcano@salud.aragob.es; María J Revillo - mjrevillo@salud.aragob.es; Carlos Martín - carlos@unizar.es; Carmen Ramírez - carmenovispos8@gmail.com;

Nalin Rastogi - nrastogi@pasteur-guadeloupe.fr; Janet Rojas - programatbvenezuela@yahoo.com; Albina Vázques de

Salas - programatbvenezuela@yahoo.com; Christophe Sola - csola@pasteur-guadeloupe.fr; Sofía Samper* - ssamper@salud.aragob.es

* Corresponding author
\end{abstract}

Published: 10 October 2006

BMC Microbiology 2006, 6:90 doi:10.1 I86/147|-2180-6-90

This article is available from: http://www.biomedcentral.com/I47I-2180/6/90

(C) 2006 Aristimuño et al; licensee BioMed Central Ltd.

This is an Open Access article distributed under the terms of the Creative Commons Attribution License (http://creativecommons.org/licenses/by/2.0), which permits unrestricted use, distribution, and reproduction in any medium, provided the original work is properly cited.

\begin{abstract}
Background: Molecular typing of Mycobacterium tuberculosis strains has become a valuable tool in the epidemiology of tuberculosis (TB) by allowing detection of outbreaks, tracking of epidemics, identification of genotypes and transmission events among patients who would have remained undetected by conventional contact investigation. This is the first genetic biodiversity study of $M$. tuberculosis in Venezuela. Thus, we investigated the genetic patterns of strains isolated in the first survey of anti-tuberculosis drug-resistance realised as part of the Global Project of Anti-tuberculosis Drug Resistance Surveillance (WHO/IUATLD).
\end{abstract}

Results: Clinical isolates (670/873) were genotyped by spoligotyping. The results were compared with the international spoligotyping database (SpolDB4). Multidrug resistant (MDR) strains (I4/I8) were also analysed by IS6 I I0-RFLP assays, and resistance to isoniazid and rifampicin was characterised.

Spoligotyping grouped $82 \%$ (548/670) of the strains into 59 clusters. Twenty new spoligotypes (SITs) specific to Venezuela were identified. Eight new inter-regional clusters were created. The Beijing genotype was not found. The genetic network shows that the Latin American and Mediterranean family constitutes the backbone of the genetic TB population-structure in Venezuela, responsible of $>60 \%$ of total TB cases studied. MDR was $0.5 \%$ in never treated patients and $13.5 \%$ in previously treated patients. Mutations in $r p o B$ gene and $k a t G$ genes were detected in $64 \%$ and $43 \%$ of the MDR strains, respectively.

Two clusters were found to be identical by the four different analysis methods, presumably representing cases of recent transmission of MDR tuberculosis. 
Conclusion: This study gives a first overview of the $M$. tuberculosis strains circulating in Venezuela during the first survey of anti-tuberculosis drug-resistance. It may aid in the creation of a national database that will be a valuable support for further studies.

\section{Background}

The World Health Organisation (WHO) estimates that if the current tools for the treatment and prevention of TB are not improved, nearly 1 billion additional people will become infected by M. tuberculosis between the 2000 and 2020. Among these, 200 million will develop the active disease and 35 million will die from TB. By the end of 2004, 199 (94\%) of 211 countries notified 4.4 million new and relapsed cases, of which 1.9 million (44\%) were new sputum smear-positive. Among these notifications, 3.7 million were from DOTS (Directly Observed Treatment Short course) areas. The Region of the Americas notified 235,187 cases in 2004 [1]. Venezuela covers an area of $916,495 \mathrm{~km}^{2}$ and has a population of around 25 million inhabitants, and has shown a marked decrease in the incidence of TB during the last years. The TB prevalence rate in 1939 was 98.6 per 100,000 inhabitants for mortality and 111 per 100,000 inhabitants for morbidity [2]. Since then, the incidence has decreased dramatically to reach 6734 cases (26 per 100,000 inhabitants), with most being confined within the 15 to 45 year age group. Nevertheless, in indigenous populations, TB incidence has remained very high (137.4 per 100,000 inhabitants) [3]. In 1982, the National Tuberculosis Control Program of Venezuela (NTP) implemented the directly observed treatment and since 1994 has used a standardised sixmonth treatment for all new TB cases with or without culture confirmation [4].

Venezuela carried out the first survey of anti-tuberculosis drug resistance during 1998-1999 as part of the Global Project of Anti-tuberculosis Drug Resistance Surveillance, coordinated by the International Union Against Tuberculosis and Lung Disease (IUATLD) and the WHO. The survey enrolled 873 patients with smear-positive TB, and living in 23 states from Venezuela [4,5]

The molecular characterisation of the isolates collected during this study was not carried out and there is no information on the major circulating clades of M. tuberculosis. The mutations involved in drug resistance and the question of whether the Beijing family of the M. tuberculosis complex had spread into Venezuela have not been studied until now. Molecular epidemiological studies have showed the widespread of this family and its association with drug-resistance [6-8].

In recent years, the genetic typing of $M$. tuberculosis complex (MTC) strains has been widely used to support con- ventional epidemiological investigations of TB outbreaks and as a tool for studying transmission dynamics. The analysis of restriction fragment length polymorphisms (RFLP), which is based on the variability of the chromosomal location and copy number of the insertion sequence IS6110, is considered the gold standard for the genotyping of MTC $[9,10]$. However, this technique is expensive for developing countries, is cumbersome and requires a large amount of highly purified DNA, and is limited for strains with fewer than six IS6110 insertions or when rapid results are needed. Spoligotyping has emerged as a robust, easy, cheap and reliable supplementary tool for the molecular epidemiological study of TB. The establishment of an international database of spoligotypes provides information on the overall diversity of strain patterns. The combination of spoligotyping with bioinformatics has been proposed as a potential tool for defining major circulating clades of tuberculosis bacilli and to analyse the complexity of global TB transmission [11-14]. Spoligotyping has also been used to track TB epidemics, detect new outbreaks, define high-risk populations and to help to verify suspected false-positive cultures due to laboratory contamination and to confirm nosocomial transmission. In conjunction with other genotyping assays, it has also been used to investigate the evolutionary genetics of the tubercle bacilli [15-18].

This present investigation aims to provide an initial idea of the genetic biodiversity of $M$. tuberculosis in Venezuela. We used spoligotyping as a first-line discriminatory test in 670 strains isolated from the 23 surveyed states during the first anti-tuberculosis drug-resistance survey. RFLP analysis of IS6110 and characterisation of the katG and rpoB genes were carried out on 14 of the 18 MDR strains included in this survey.

\section{Results \\ Study of population}

A total of 873 patients with sputum smear-positive pulmonary $\mathrm{TB}$ were included in the survey to determine the initial prevalence and acquired resistance to the principal anti-TB drugs. Of these, 769 (88\%) had never been treated for tuberculosis and the other 104 (12\%) had previously received treatment (Table 1 ). Of the 873 isolates, 783 $(90 \%)$ were sensitive to all four evaluated drugs and 90 (10.3\%) showed resistance to at least one drug. Among the 769 cultures of the never treated patients, $58(7,5 \%)$ were resistant to one or more drugs whereas the remaining 711 (92.5\%) were susceptible to all four tested drugs. 
Table I: Prevalence of M. tuberculosis drug resistance in Venezuela, 1998-1999.

\begin{tabular}{|c|c|c|c|}
\hline & $\begin{array}{c}\text { Never treated } \\
\mathrm{n}(\%)\end{array}$ & $\begin{array}{l}\text { Previously treated cases } \\
\qquad \mathrm{n}(\%)\end{array}$ & $\begin{array}{l}\text { Total } \\
\mathrm{n}(\%)\end{array}$ \\
\hline Total number of cultures & $769(88)$ & $104(12)$ & $873(100)$ \\
\hline Susceptible to all drugs & $7 I I(92.5)$ & $72(69.2)$ & $783(90)$ \\
\hline Resistant to one or more drugs & $58(7.5)$ & $32(30.8)$ & $90(10.3)$ \\
\hline Resistant to only one drug & $38(4.9)$ & $12(1.5)$ & $50(5.7)$ \\
\hline $\mathrm{H}$ & $13(1.7)$ & $6(5.8)$ & $19(2.1)$ \\
\hline $\mathrm{R}$ & $3(0.4)$ & $3(2.9)$ & $6(0.6)$ \\
\hline$E$ & $\mathrm{I}(0.1)$ & $0(0.0)$ & $\mathrm{I}(0.1)$ \\
\hline S & $21(2.7)$ & $3(2.9)$ & $24(2.7)$ \\
\hline MDR (Multidrug resistance) & $4(0.5)$ & $14(13.5)$ & $18(2.1)$ \\
\hline $\mathrm{H}+\mathrm{R}$ & $2(0.3)$ & $4(3.8)$ & $6(0.7)$ \\
\hline $\mathrm{H}+\mathrm{R}+\mathrm{S}$ & $\mathrm{I}(0.1)$ & $5(4.8)$ & $6(0.6)$ \\
\hline $\mathrm{H}+\mathrm{R}+\mathrm{E}$ & $0(0.0)$ & $2(1.9)$ & $2(0.2)$ \\
\hline $\mathrm{H}+\mathrm{R}+\mathrm{E}+\mathrm{S}$ & $\mathrm{I}(0.1)$ & $3(2.9)$ & $4(0.4)$ \\
\hline Other patherns & $16(2.1)$ & $6(5.8)$ & $22(2.5)$ \\
\hline $\mathrm{H}+\mathrm{E}$ & $2(0.3)$ & $\mathrm{I}(1.0)$ & $3(0.3)$ \\
\hline $\mathrm{H}+\mathrm{S}$ & $10(1.3)$ & $3(2.9)$ & $13(1.5)$ \\
\hline$E+S$ & $2(0.3)$ & $0(0.0)$ & $2(0.2)$ \\
\hline $\mathrm{R}+\mathrm{E}$ & $\mathrm{I}(0.1)$ & $0(0.0)$ & $\mathrm{I}(0.1)$ \\
\hline $\mathrm{H}+\mathrm{E}+\mathrm{S}$ & $\mathrm{I}(0.1)$ & $0(0.0)$ & $\mathrm{I}(0.1)$ \\
\hline $\mathrm{R}+\mathrm{E}+\mathrm{S}$ & $0(0.0)$ & $2(1.9)$ & $2(0.2)$ \\
\hline
\end{tabular}

Never treated patients

Total $\mathrm{H}$ resistance: $30 / 769 \times 100=4 \%$

Total $R$ resistance: $8 / 769 \times 100=1 \%$

Total E resistance: $8 / 769 \times 100=0.9 \%$

Total S resistance: $36 / 769 \times 100=0.7 \%$

Total MDR resistance: $4 / 769 \times 100=0.5 \%$

Previously treated patients

Total $\mathrm{H}$ resistance: $24 / 104=23 \%$

Total $R$ resistance: $19 / 104=18.3 \%$

Total $\mathrm{E}$ resistance: $8 / 104 \times 100=7.7 \%$

Total S resistance: $16 / 104 \times 100=15.3 \%$

Total MDR resistance: $14 / 104=13.5 \%$

Results of the first survey of anti-tuberculosis drug resistance in Venezuela during 1998-1999.

Resistance to drugs: Isoniazid $(H)$, Rifampicin (R), Ethambutol $(E)$, Streptomycin $(S)$ in never treated and previously treated patients.

The rate of MDR was $0.5 \%$ (4) and $13.5 \%$ (14) in strains of never treated and previously treated patients respectively. Total resistance to INH and RIF in never treated patients was $4 \%$ (30 patients) and $1 \%$ (8 patients), respectively. This rate was $23 \%$ (24 patients) and $18.3 \%$ (19 patients) respectively in previously treated patients (Table 1). Most of the patients with drug-resistant isolates (74/ $90-82 \%$ ) were aged between 15 and 54 years. Among the 90 patients resistant to one or more drugs, $72 \%$ were male.

\section{Analysis of the Spoligotyping patterns and comparison with an international database}

Of the $873 \mathrm{M}$. tuberculosis isolates from the national survey, $670(77 \%)$ could be typed satisfactorily by spoligotyping. There were isolates of the 23 states surveyed among the genotyped strains (Fig 1). The spoligotype (SIT = Spoligo-International Type Number, a common pattern shared by two or more isolates) was determined by comparing our obtained patterns with those in the interna- tional spoligotype database of the Institute Pasteur of Guadeloupe [19]. At the time of the study, the database contained patterns for 29,363 clinical isolates, grouped into 1689 SITs. Of the 670 strains analysed, 79 (12\%) were non-SIT (orphan patterns) according to spoligotype database and the remaining 591 (88\%) isolates clustered into 102 SITs. Of these, 74 were found in the international database. The inclusion of our data to SpolDB4 created 28 new SITs, 20 of them were specifically created with Venezuelan isolates. These were identified with the SITs: 1691, 1692, 1693, 1696, 1698, 1699, 1700, 1701, 1702, 1703, $1704,1705,1707,1711,1713,1714,1715,1716,1718$ and 1719) (Table 2). The new SIT 1691 (characterised by the absence of spacers 3,13,15,21-24 and 33-36) comprised 14 strains isolated of nine provinces from Venezuela (Dtto. Federal, Carabobo, Aragua, Anzoátegui, Sucre, Apure, Barinas, Portuguesa and Bolivar). Whereas the remaining new endemic SITs comprised between two and five isolates. Eight new inter-region clusters were created (SITs: 1694, 1695, 1697, 1706, 1708, 1709, 1710, 
Table 2: Description of the $M$. tuberculosis clusters found in Venezuela.

\begin{tabular}{|c|c|c|c|c|c|}
\hline ISIT & Spoligotyping patterns -Binary description & $2 n$ & $\%$ & ${ }^{3}$ Clade & ${ }^{4} \mathbf{C}-\mathbf{I}$ \\
\hline 17 & 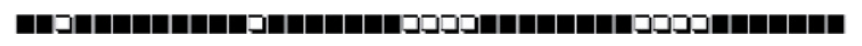 & 122 & 21.94 & LAM-2 & Ubiquitous \\
\hline 42 & 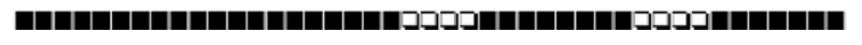 & 86 & 15.47 & LAM-9 & Ubiquitous \\
\hline 93 & 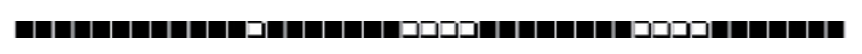 & 70 & 12.59 & LAM-5 & Ubiquitous \\
\hline 53 & שח & 26 & $4.6 \mathrm{~S}$ & T-I & Ubiquitous \\
\hline 20 & 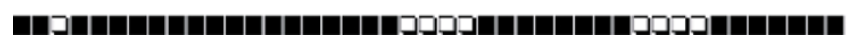 & 26 & 4.63 & LAM-I & Ubiquitous \\
\hline 605 & 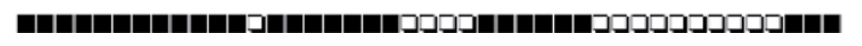 & 18 & 3.24 & $\cup$ & Loc (VEN/USA) \\
\hline 1691 & 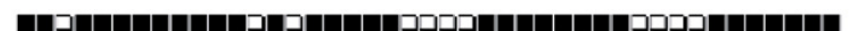 & 14 & 2.52 & LAM-2 & Endemic (VEN) \\
\hline 60 & שחسכدככسחמם & 13 & 2.39 & LAM-4 & Ubiquitous \\
\hline 905 & 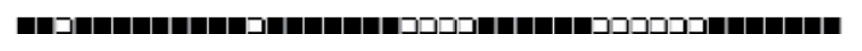 & 10 & 1.60 & $\cup$ & Loc (VEN-USA-ARG) \\
\hline 118 & |חסכבפבן & 9 & 1.61 & $\mathrm{~T}-2$ & Ubiquitous \\
\hline 50 & 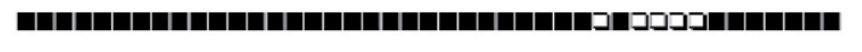 & 9 & 1.61 & $\mathrm{H}-3$ & Ubiquitous \\
\hline 51 & | וסככבם & 8 & 1.43 & $T-I$ & Ubiquitous \\
\hline 333 & 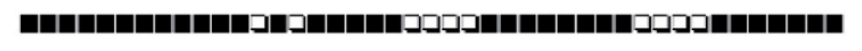 & 7 & 1.25 & LAM-5 & Loc (GUP-GUF-HTI-VEN) \\
\hline 960 & שכدכבם & 5 & 0.90 & $U$ & Loc (VEN-USA) \\
\hline 34 & | & 5 & 0.90 & $S$ & Ubiquitous \\
\hline 194 & 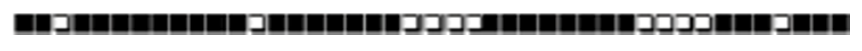 & 5 & 0.90 & LAM-4 & Loc (USA-BRA-MEX-VEN) \\
\hline 1696 & ח שכدכ & 5 & 0.90 & LAM-5 & Endemic (VEN) \\
\hline 47 & | اسدلدردس & 5 & 0.90 & $\mathrm{H}-\mathrm{I}$ & Ubiquitous \\
\hline 130 & חבכבכב & 4 & 0.71 & LAM-3 & Ubiquitous \\
\hline 150 & | מחככבכו & 4 & 0.71 & LAM-9 & Ubiquitous \\
\hline 397 & | וחבפבפכבו & 4 & 0.71 & $U$ & Loc (ITA-BRA-ARG-USA-VEN) \\
\hline 1692 & 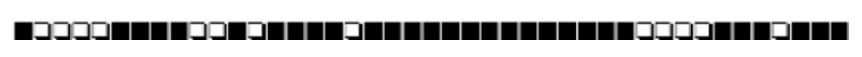 & 4 & 0.71 & $\cup$ & Endemic (VEN) \\
\hline 1700 & 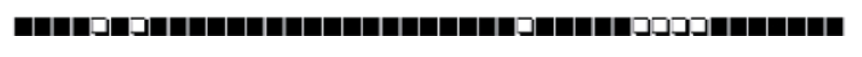 & 4 & 0.71 & $T-I$ & Endemic (VEN) \\
\hline 33 & 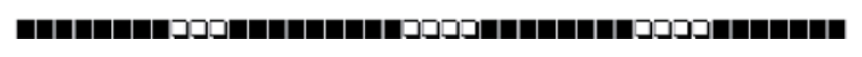 & 3 & 0.54 & LAM-3 & Ubiquitous \\
\hline 44 & שכנבכם & 3 & 0.54 & $\mathrm{~T}-4$ & Ubiquitous \\
\hline 58 & الدנب & 3 & 0.54 & T-5 & Ubiquitous \\
\hline 64 & 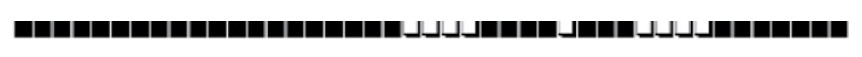 & 3 & 0.54 & LAM-6 & Ubiquitous \\
\hline 162 & חשכدכבם & 3 & 0.54 & $U$ & Loc (ARG-VEN-USA-FIN-FXX-ITA) \\
\hline 376 & 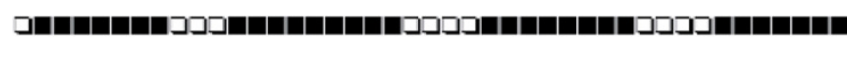 & 3 & 0.54 & LAM-3 & Loc (VEN-USA) \\
\hline 578 & 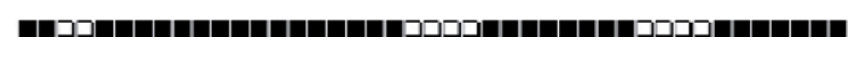 & 3 & 0.54 & LAM-9 & Loc (USA-VEN) \\
\hline 1698 & 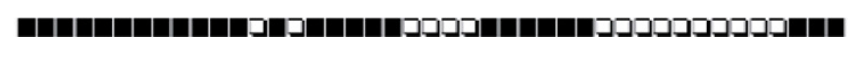 & 3 & 0.54 & $U$ & Endemic (VEN) \\
\hline 1701 & 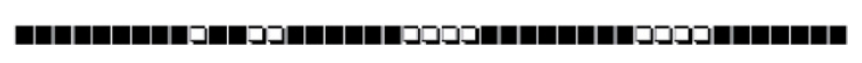 & 3 & 0.54 & LAM-9 & Endemic (VEN) \\
\hline 1702 & 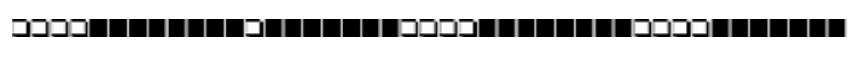 & 3 & 0.54 & LAM-5 & Endemic (VEN) \\
\hline 1705 & 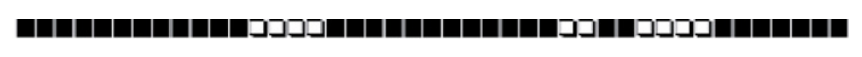 & 3 & 0.54 & T-I & Endemic (VEN) \\
\hline 1713 & 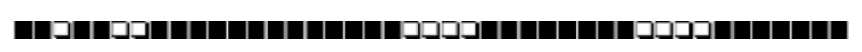 & 3 & 0.54 & LAM-I & Endemic (VEN) \\
\hline
\end{tabular}


Table 2: Description of the M. tuberculosis clusters found in Venezuela. (Continued)

\begin{tabular}{|c|c|c|c|c|c|}
\hline 1718 & 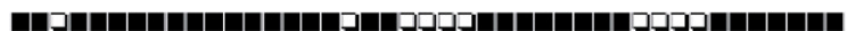 & 3 & 0.54 & LAM-9 & Endemic (VEN) \\
\hline 52 & 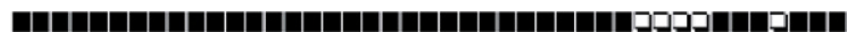 & 2 & 0.36 & $\mathrm{~T}-2$ & Ubiquitous \\
\hline 62 & 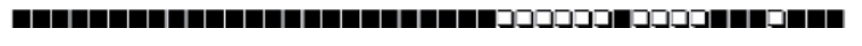 & 2 & 0.36 & $\mathrm{H}-\mathrm{I}$ & Ubiquitous \\
\hline 71 & 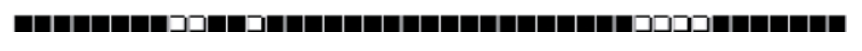 & 2 & 0.36 & S & Ubiquitous \\
\hline 106 & 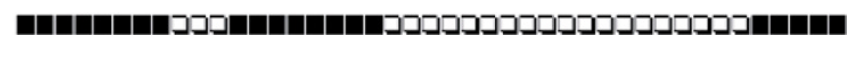 & 2 & 0.36 & $U$ & Loc (CUB-ECU-M EX-USA-VEN) \\
\hline 132 & 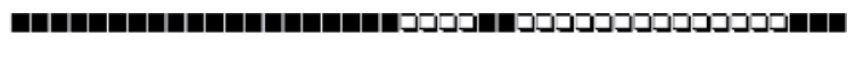 & 2 & 0.36 & $U$ & Loc (ESP-AUS-BRA-VEN) \\
\hline 167 & 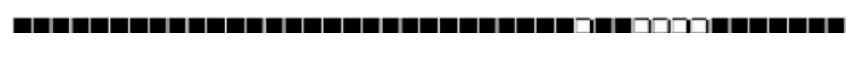 & 2 & 0.36 & $\mathrm{~T}$ & Ubiquitous \\
\hline 178 & 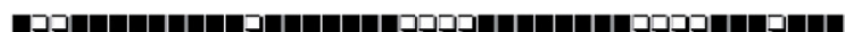 & 2 & 0.36 & LAM-4 & Loc (CUB-SEN-VEN) \\
\hline 196 & שכבכבמ & 2 & 0.36 & T-I & Ubiquitous \\
\hline 388 & |חבכבכבחו & 2 & 0.36 & LAM-9 & Ubiquitous \\
\hline 389 & 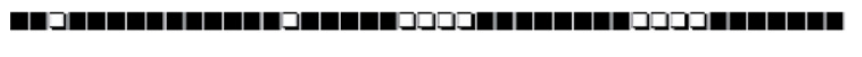 & 2 & 0.36 & LAM-I & Loc (BRA-PRT-FIN-VEN) \\
\hline 430 & 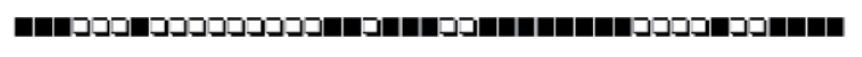 & 2 & 0.36 & $\mathrm{~T}-4$ & Loc (USA-VEN) \\
\hline 1166 & 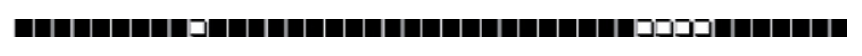 & 2 & 0.36 & T-I & Ubiquitous (MWI-USA-VEN) \\
\hline 1661 & 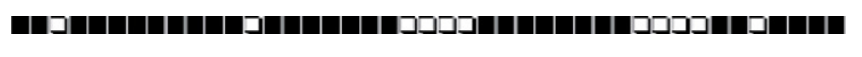 & 2 & 0.36 & LAM-2 & Loc (VEN-BRA) \\
\hline 1693 & 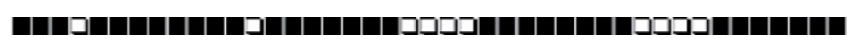 & 2 & 0.36 & LAM-5 & Endemic (VEN) \\
\hline 1699 & 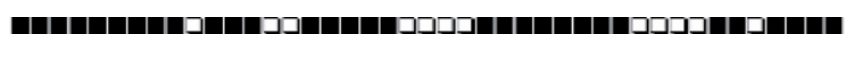 & 2 & 0.36 & LAM-9 & Endemic (VEN) \\
\hline 1703 & 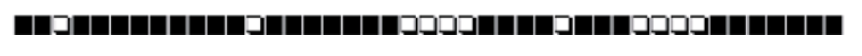 & 2 & 0.36 & LAM-9 & Endemic (VEN) \\
\hline 1704 & 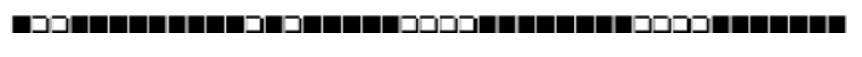 & 2 & 0.36 & LAM-5 & Endemic (VEN) \\
\hline 1707 & 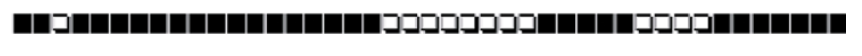 & 2 & 0.36 & $\mathrm{~T}-\mathrm{I}$ & Endemic (VEN) \\
\hline 1711 & 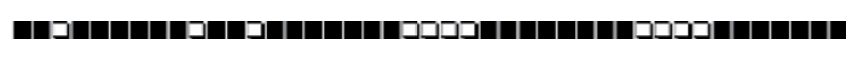 & 2 & 0.36 & LAM-2 & Endemic (VEN) \\
\hline 1714 & וחסכבכבי & 2 & 0.36 & LAM-9 & Endemic (VEN) \\
\hline 1715 & 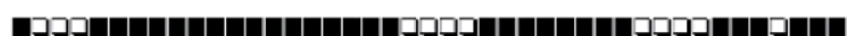 & 2 & 0.36 & LAM-4 & Endemic (VEN) \\
\hline 1716 & שבבדבי & 2 & 0.36 & $\mathrm{~T}-3$ & Endemic (VEN) \\
\hline 1719 & 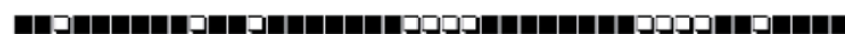 & 2 & 0.36 & LAM-2 & Endemic (VEN) \\
\hline 1694 & 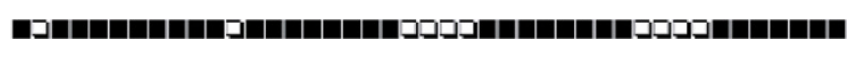 & I & 0.18 & LAM-5 & Loc (VEN-USA)-Cluster inter-region \\
\hline 1695 & 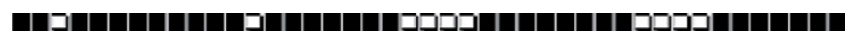 & 1 & 0.18 & LAM-2 & Loc (VEN-BRA)-Cluster inter-region \\
\hline 1697 & 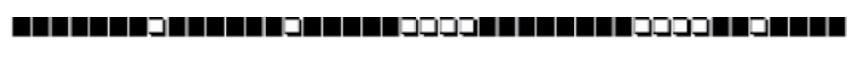 & 1 & 0.18 & LAM-9 & Loc (VEN-FXX)-Cluster inter-region \\
\hline 1706 & 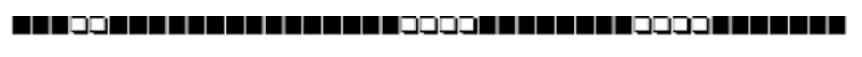 & I & 0.18 & LAM-9 & Loc (VEN-USA)-Cluster inter-region \\
\hline 1708 & 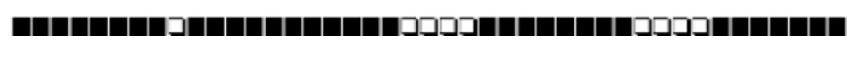 & 1 & 0.18 & LAM-9 & Loc (VEN-LVA)-Cluster inter-region \\
\hline 1709 & 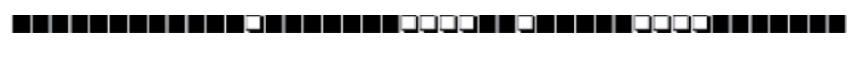 & 1 & 0.18 & LAM-5 & Loc (VEN-USA)-Cluster inter-region \\
\hline 1710 & 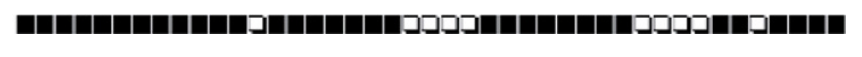 & I & 0.18 & LAM-4 & Loc (VEN-NLD)-Cluster inter-region \\
\hline 1717 & 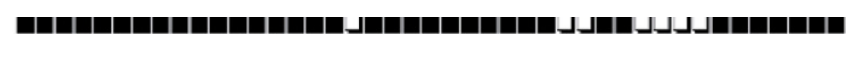 & 1 & 0.18 & $x-1$ & Loc (VEN-AUS)-Cluster inter-region \\
\hline Total & & 556 & 100 & & \\
\hline
\end{tabular}

ISIT, designation of the spoligotype in the international database [19]. ${ }^{2 n}$ : Number of strains. ${ }^{3}$ Clade: defined mainly as described [20, 2I] LAM: Latin American and Mediterranean, $\mathrm{H}$ : Haarlem, T (ill-defined T clade), S: S clade, X: X clade, U: Undesignated. ${ }^{4} \mathrm{C}-\mathrm{I}$ : qualifier that tentatively defines an SIT as Endemic, Loc: localized or ubiquitous, as defined in Filliol et al. [20]. Geographic distribution: VEN: Venezuela, USA: United States of America, BRA: Brazil, GUP: Guadeloupe, GUF: French Guiana, HTI: Haiti, ESP: Spain, ECU: Ecuador, ARG: Argentina, CUB: Cuba, MEX: Mexico, SEN: Senegal, PRT: Portugal, FIN: Finland, ITA: Italy, MWI: Malawi, FXX: Metropolitan France, LVA: Latvia, NLD: The Netherlands, AUS: Australia. 


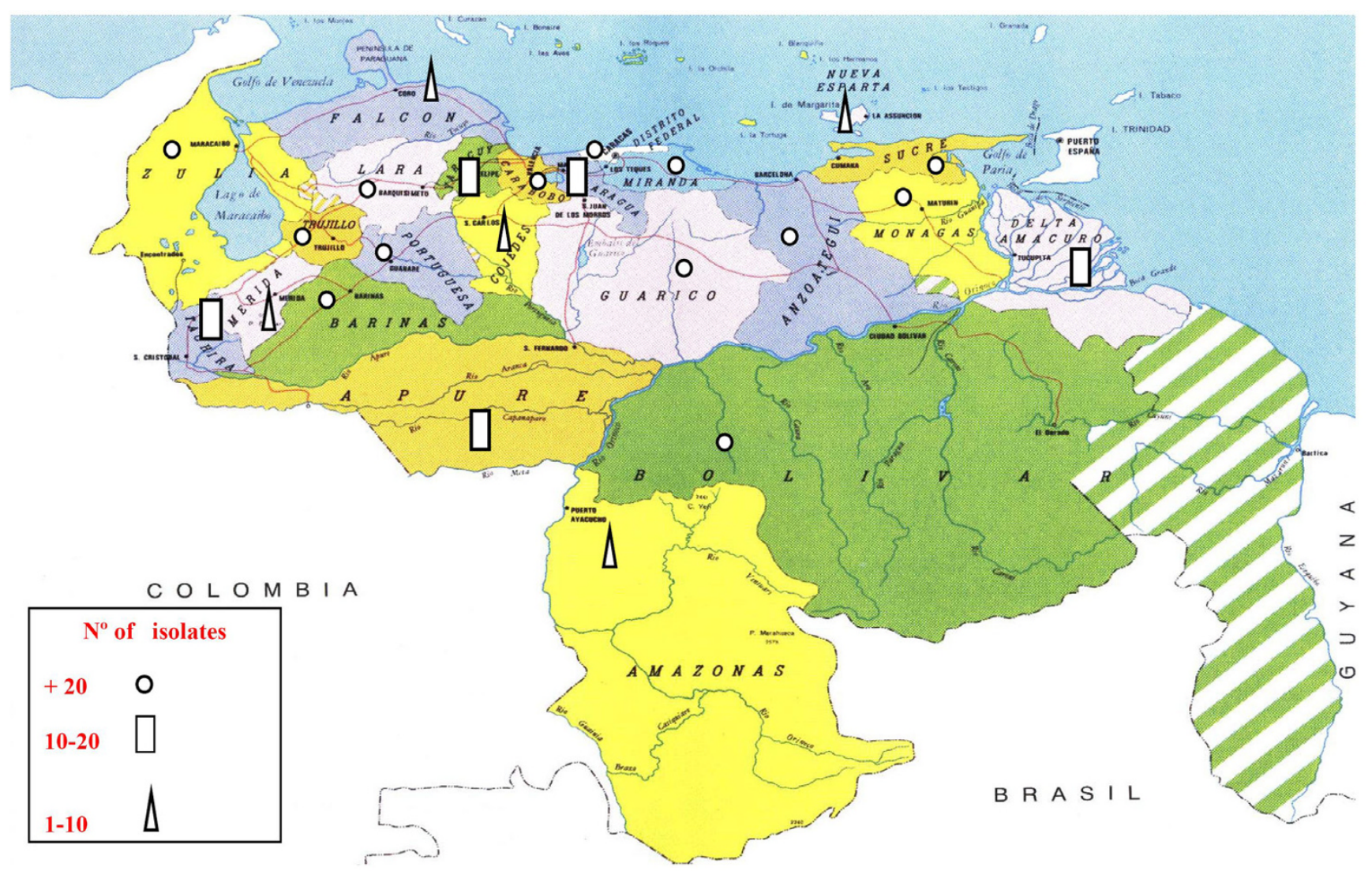

Figure I

Distribution and number of isolates studied by spoligotyping in 23 provinces from Venezuela.

1717) with one Venezuelan and one non-Venezuelan isolate from USA, France, Latvia, The Netherlands, Brazil and Australia (Table 2). Three isolates of indigenous patients from the Warao ethnic group (Delta Amacuro State) created the new clusters SITs 1716, 1718 and the interregional SIT 1717.

Of the 591 isolates, 548 (93\%) were grouped into 59 clusters (the number of strains in each cluster ranged from 2 to 112 ). Among the 59 clusters, 18 contained five or more isolates, which we defined as major spoligotypes. The total number of these isolates comprised $80 \%(n=443)$ of the clustered isolates. The major SITs were: 17, 42, 93, 53, 20, 605, 1691, 60, 905, 118, 50, 51, 333, 960, 34, 194, 1696 and 47 (Table 2).

The SITs found in our study allowed the classification of the isolates into representative patterns describing families or clades [14,20], as $74 \%(411 / 556)$ belong to the Latin American and Mediterranean (LAM) family (subclades $2,9,5,1,4,3,6), 13 \%(70 / 556)$ belong to the illdefined $\mathrm{T}$ (sub-clades 1,2,3,4,5), 3\% (16/556) belong to the Haarlem family (sub-clades 1 and 3$), 1 \%(1 / 556)$ grouped to the S family, and $9 \%(51 / 556)$ were classified undesignated (SITs: 605, 905, 960, 397, 1692, 162, 1698, 106, 239, 443, 606 and 821) (Table 2). The geographic distribution (C1) [20] of the shared types was as follows: 24 SITs were ubiquitous types (Ubiq) or are widespread in the world, 20 SITs were endemic (Venezuela) and 23 SITs were geographically limited (Loc) (Table 2). We observed no strains belonging to the Beijing family among the 670 clinical isolates analysed.

\section{Phylogeny reconstruction}

We used Biolayout software to build a genetic network of the SITs detected in Venezuela (Fig. 2) [22]. In this model, the size of the circles indicating the SIT is proportional to their quantitative distribution in this study. We used maximum parsimony principles and assumed an underlying evolution model of the DR locus by deletion of single or contiguous direct variable repeats (DVRs) to link most, if not all, of the spoligotypes found in this study. Each arrow represents a phylogenetic link between two spoligotypes that differ by a genetic change, whether this change corresponds to single or many contiguous DVRs deletion. Fig 2 shows the phylogenetic clades prevalents as well as that 


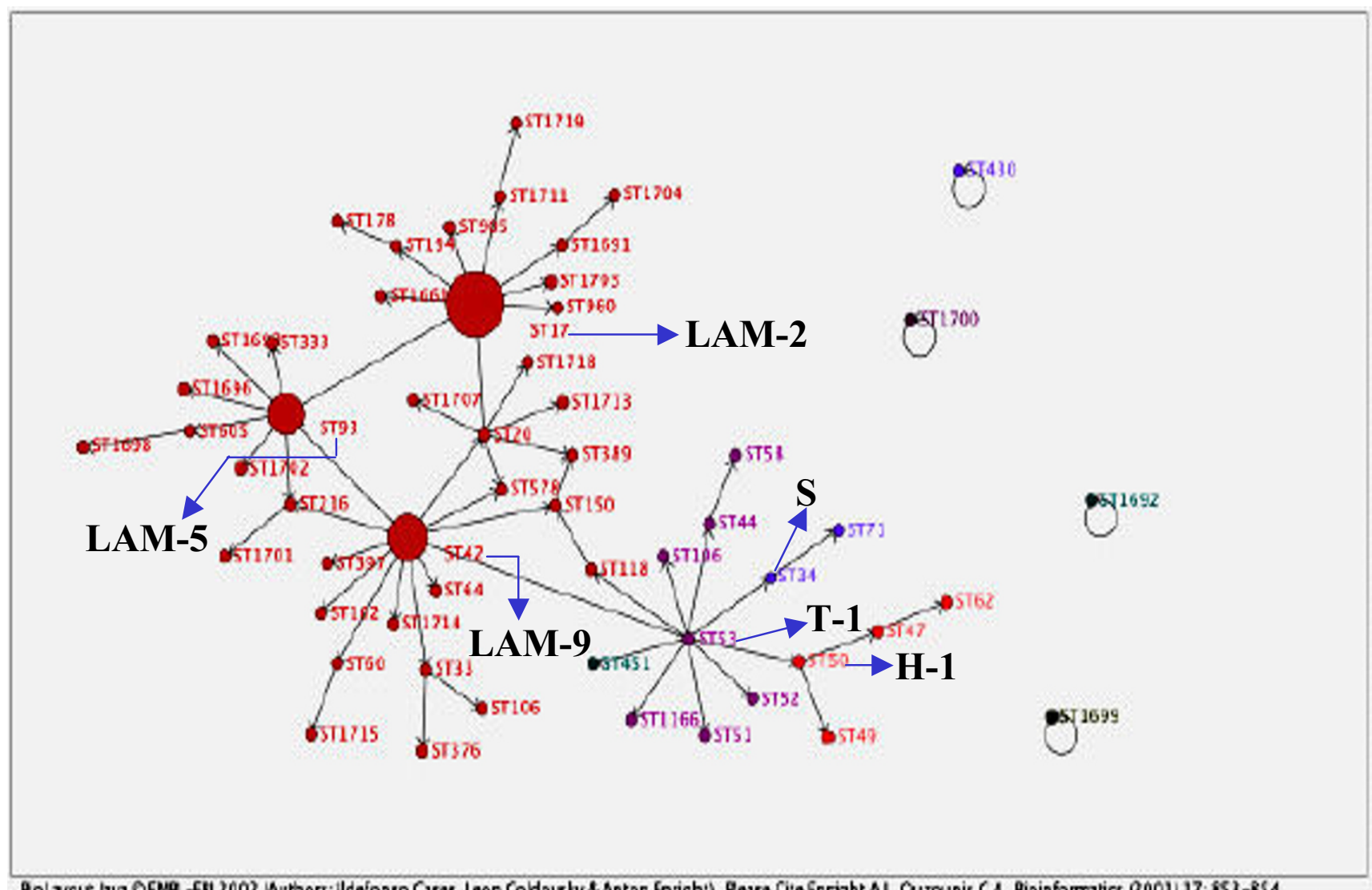

Figure 2

Genetic network of spoligotypes detected in Venezuela using parsimony principles and the Biolayout software. Each black arrow represents a phylogenetic link between two spoligotypes differing by a genetic change. The size of the circles representing the spoligotypes is proportional to the number of isolates in each cluster. Prevalent phylogenetic clades in Venezuela: LAM (2-9-5); T-I; Haarlem (H-I) and S are named. See text for details.

three variants of the LAM family - LAM2 (SIT17), LAM9 (SIT42), and LAM5 (SIT93) - constitute the backbone of the genetic TB population-structure in Venezuela. A more detailed picture will require further investigations using complementary genetic markers.

\section{Analysis by IS6 I I 0-RFLP typing, katG and rpoB genes characterisation}

We analysed 14 (78\%) of the 18 isolates identified as MDR using phenotypic methods. While Spoligotyping grouped 10 strains in 2 clusters (SITs 17 and 42) and 4 unique isolates were identified as SIT 60, 130, 1705 and 0 (orphan pattern), RFLP analysis classified eight (57\%) isolates as unique, with the other six (43\%) isolates being grouped into three clusters of two isolates (Fig 3). The number of IS6110 per strain varied from 9 to 15 . Of the three clusters, two contained isolates from patients from two different states and one cluster contained isolates from patients living in the same state (Fig 3). We investi- gated these isolates to identify the mutation associated with INH resistance (katG gene) and RIF resistance ( $r p o B$ gene). As summarized in the Fig 3, we found the Ser315Thr mutation in the katG gene in $6(43 \%)$ of the 14 isolates, identified as: VEN 479, 624, 769, 605, 611 and 617.

Mutations in the $r p o B$ gene were detected in $9(64 \%)$ of the 14 isolates: VEN 479, 624, 738, 769, 357, 517, 605 611 and 617 . No rpoB mutations were found in 5 (36\%) of the 14 strains phenotypically identified as MDR, which corresponded to 1 previously treated patient and 4 never treated patients. Two different mutations were observed, which occurred in codon 531 and codon 516 (Fig 3). The specific mutation TCG-TTG (Ser/Leu) of the codon 531 was detected in 5 isolates (VEN 624, 738, 769, 357, 517) and the mutation GAC-GTC (Asp/Val) of the codon 516 was found in 4 isolates (VEN 479, 605, 611 and 617). Six 

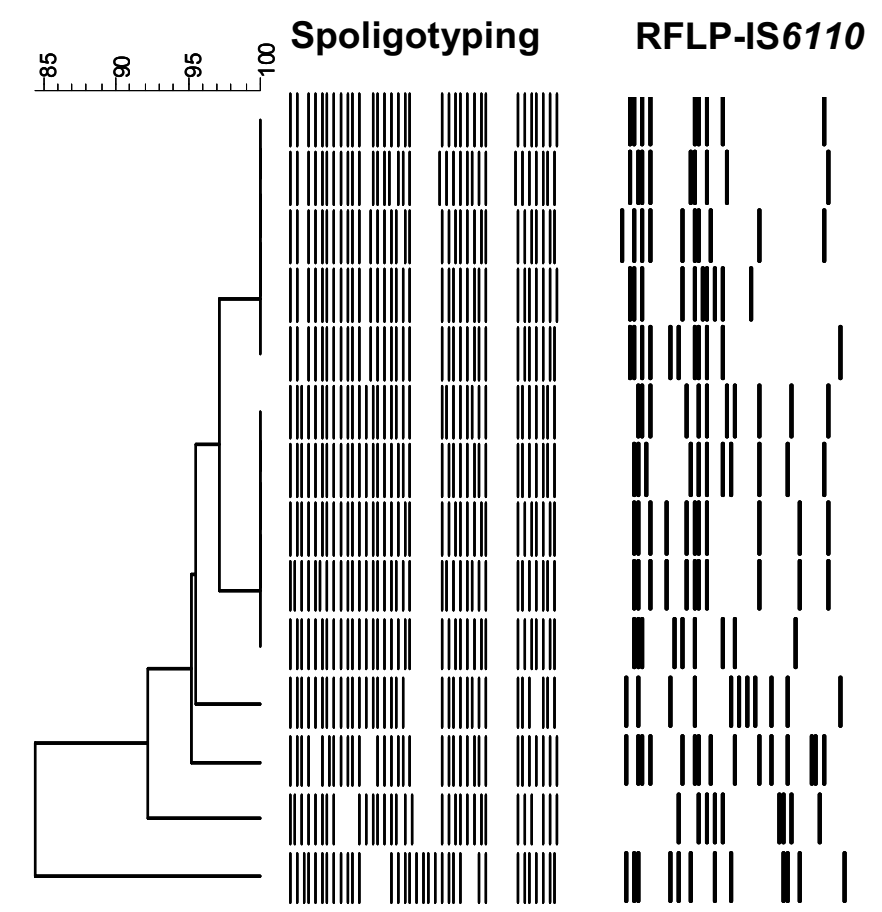

katG
0
1
1
0
1
0
0
1
1
1
0
0
0
0

$\begin{aligned} \text { rpoB } & \text { Strain } \\ 1 & \text { VEZ } 399 \\ 6 & \text { VEZ 479 } \\ 10 & \text { VEZ 624 } \\ 10 & \text { VEZ 738 } \\ 10 & \text { VEZ 769 } \\ 10 & \text { VEZ 357 } \\ 10 & \text { VEZ 517 } \\ 6 & \text { VEZ 605 } \\ 6 & \text { VEZ 611 } \\ 6 & \text { VEZ 617 } \\ 1 & \text { VEZ 332 } \\ 1 & \text { VEZ } 313 \\ 1 & \text { VEZ } 491 \\ 1 & \text { VEZ 585 }\end{aligned}$

State

SIT

Mérida

Monagas

Sucre

Zulia

Zulia

Lara

Portuguesa

Sucre

Sucre

Sucre

Guarico

60

Cojedes

0

Monagas

Portuguesa

1705

\section{Figure 3}

IS6 I I 0 RFLP, katG and rpoB gene mutations of I 4 MDR isolates clustered by Spoligotyping. Dendogram based on the Spoligotyping method of I4 MDR strains showing the IS6 I I 0 RFLP, the codon 3 I5 in katG gene (0: No Ser3 I5Thr mutation, I: Ser3 I5Thr) and rpoB gene mutations (I: No mutation, 6: Asp5 I6Val/GAC-GTC, I0: Ser53 ILeu/TCG-TTG). Strain: identification of the isolate. State: origin of the isolate. SIT: spoligo-international type number [19].

(43\%) of the 14 isolates had mutations in both the katG and $r p o B$ genes (VEN 479, 624, 769, 605, 611 and 617).

Finally, when the three clusters were studied by RFLP analysis of IS6110, spoligotyping, and mutations of the katG and $r p o B$ genes, we found that only two of them were identical by the four different methods, presumably revealing cases of recent transmission of MDR tuberculosis (Fig 3 ).

\section{Discussion}

In 1994, the WHO and IUATLD launched a Global Project on Anti-Tuberculosis Drug resistance surveillance to assess the global extent of drug resistance. During 19981999, the NTP in Venezuela carried out the first national drug resistance survey through out the entire country for a period of nine months. The sampling method was the proportionate cluster method and the total of 873 patients were tested. The Venezuelan NTP has a long history of tuberculosis control and the results of the survey showed a very low prevalence $(0.5 \%)$ of MDR-TB in never treated patients, similar to those reported in Canada,
Cuba, Uruguay, and Chile, which are countries with effective NTCPs [4,5]. However, the prevalence of resistance to at least one drug among the previously treated cases was $30.8 \%$ and MDR-TB was $13.5 \%$.

We used spoligotyping to molecularly characterise 670 $(77 \%)$ of the 873 isolates, including isolates of the 23 states surveyed. It was not possible to analyse all isolates by RFLP analysis IS6110. Nevertheless, as the molecular epidemiology of MDR M. tuberculosis in Venezuela is not know, we investigated the most of MDR isolates detected in the survey using spoligotyping, RFLP analysis of IS6110 and point mutations of the katG and $r p o B$ genes.

Comparison of our spoligo-patterns with the international spoligotyping database revealed that 74 SITs had already been identified. We describe 20 new SITs specific to Venezuela that were found in $75 \%$ of the 23 provinces surveyed and show that these types are extensively dispersed. The six most prevalent spoligotypes (SITs 17, 42, 93, 53, 20 and 605) included the half of all the isolates. Among the clades of $M$. tuberculosis complex described as 
harbouring specific spoligotypes, $89 \%$ of the isolates studied belonged to three major genotypic families (LAM, T and Haarlem). The majority of them belonged primarily to the LAM family, which has a high prevalence in LatinAmerica, the Caribbean and the Mediterranean region. This family recently was reclassified in 12 sub-clades [21] and in this study we identified SITs corresponding to the sub-clades LAM-2, 9, 5, 1, 4, 3 and 6. However, the genetic network of spoligotypes showed that the LAM-2, LAM-9, and LAM-5 do indeed constitute the backbone of the genetic TB population-structure in Venezuela. A more detailed picture of this network would require further investigations using complementary genetic markers to better identity the clinical isolates within the LAM superfamily of M. tuberculosis, which is highly prevalent in Venezuela.

The "ill-defined" T genetic family encountered in different regions of the world [20] was the second most common family. Within this family we found SITs that belonged to the sub-clades T-1, 2, 3, 4 and 5 [21]. We also found some isolates belonging to the Haarlem family, sub-clades $\mathrm{H}-1$ and H-3. This family has a European origin and has been described in the Caribbean and Central America, suggesting that it is remnant of the European colonisation $[23,24]$. The Beijing/W genotype was not detected in this study.

Our finding of seven new isolates belonging to SIT 333 (LAM-5), which has been reported in Guadeloupe, French Guiana, Haiti and Venezuela, suggest a common origin. SIT 605 had been reported in the international database as only being found in Venezuela and the USA, and our study adds other 18 clinical isolates, to this SIT, from patients living in seven Venezuelan provinces. Further studies are needed for a better understanding of the distribution of these spoligopatterns.

When the Venezuelan isolate spoligopatterns were added to the international database, eight new inter-regional clusters were created by matches with identical patterns from USA, Brazil, France, Latvia, Australia and The Netherlands. Curiously, one of these new inter-regional clusters (ST 1717), which included an Australian isolate, shared a pattern with one of our Venezuelan isolates belonging to an indigenous patient from the Delta Amacuro state.

We characterised the $k a t G$ and $r p o B$ genes in $78 \%(14 / 18)$ of the MDR strains isolated in the survey. We observed that $64 \%$ of the isolates had a mutation in the rpoB gene, whereas other studies have reported mutations in the 81bp core region in more $90 \%$ of MDR strains [25-27]. It has been reported that a mutation outside of the 81-bp rpoB region associated with RIF resistance, and the heteroresist- ance caused by a mixture of mycobacterial subpopulations with different susceptibilities to RIF may influence the sensitivity of the molecular tests for detecting resistance [28]. In our case, the rifampicin-resistance of these strains had been confirmed by two phenotypic methods, however the mutation in the $r p o B$ gene was no detected in five of the fourteen strains analysed. Nevertheless, a new test to confirm the resistance of those strains could not be carried out because the cultures of the strain genotyped were not available. The Ser531Leu and Asp516Val mutations detected in this study are among the most common observed worldwide [29-31].

Mutations in the kat $G$ gene have been reported between 20 and $80 \%$ of INH resistant $M$. tuberculosis strains. The mutation Ser-Thr at codon 315 of katG is the most common [32]. In our study, $43 \%$ of the isolates showed this mutation, consistent with other studies [33,34]. Other mutations in of this gene and other gene regions, such as the inhA locus, the kasA, $n d h$, oxyR-ahpC intergenic region, have been implicated in INH resistance. However, we did not evaluate these mutations.

The characterisation of $r p o B$ could discriminate between the three clusters grouped by RFLP analysis of IS6110 and by spoligotyping, as only one showed identical mutations suggesting a recent transmission of MDR tuberculosis [31]. This cluster contained isolates recovered from the same province. The other two clusters had different resistance-associated mutations, indicating that these isolates had acquired mutations independently, and were probably transmitted before the acquisition of drug resistance.

There is limited information regarding the distribution of M. tuberculosis complex genotypes as well as few molecular studies on MDR strains have been carried out in the most Latin American countries. A recent study describing the genetic diversity of $M$. tuberculosis complex and the world-wide distribution of spoligopatterns [21] showed only a limited number of registered strains, particularly in regions outside the immediate vicinity of Venezuela. Greater financial means are needed to implement an adequate infrastructure and to develop molecular typing techniques for the national reference laboratory at NTP, which will be an important tool for the control programmes in these countries.

Although Venezuela has had, a well functioning NTP during many years, the proportion of immigrants from neighbouring countries with a high incidence of TB and MDR strains, the reduction of TB control activities, and a similar decrease in the locating and treatment of cases among indigenous populations may worsen the current TB situation in the coming years. Other national studies incorpo- 
rating other molecular epidemiology methods are needed to evaluate the actual situation of MDR in Venezuela.

\section{Conclusion}

As it is important to clarify the molecular epidemiological characteristics for effective tuberculosis control, we used spoligotyping as a first-line discriminatory test. This is the first genetic biodiversity study of $M$. tuberculosis in Venezuela and our results should be considered a starting point for the creation of a national genotype database to support the National Tuberculosis Control Program in Venezuela.

\section{Methods}

\section{Bacterial strains, drug resistance assays and patients}

The study used isolates collected within the framework of first anti-tuberculosis drug-resistance survey carried out during 1998-1999 by the NTP of Venezuela. This study included patients living in the 23 provinces of Venezuela, with no distinction of sex and age. Information on the patients - sex, age, and previous history of TB and treatments - were collected by a standard questionnaire for all patients presenting with bacteriologically confirmed TB by the laboratories of the NTP.

The specimens from patients were collected and sent to the National Reference Laboratory (NRL) at the NTP for culture in Lowenstein-Jensen medium. All isolates were identified as $M$. tuberculosis complex using biochemical tests: production of niacina, catalasa activity, nitrate reduction, pigment production and growth. Drug susceptibility testing against Isoniazid (INH), Rifampicin (RIF), Ethambutol (ETB) and Streptomycin (STM) was carried out using the proportion method [35] and the BACTEC 460 radiometric method [36]. The supranational laboratory assigned by the Pan American Health Organization/ WHO to Venezuela was the National Institute for Food Protection and Zoonosis (INPAZ), Argentina, which was later replaced by the National Laboratory of Santiago, Chile, as the supranational laboratory. Spoligotyping of $670(77 \%)$ of the 873 clinical isolates, was carried out in the Laboratory of Mycobacterial Genetics, University of Zaragoza, Spain. The remaining isolates could not be analysed because some presented or contaminated cultures what prevented the analysis or the poor quality of the DNA showed not clearly defined spoligopatterns. A sufficient quality of genomic DNA for IS6110 RFLP fingerprinting was obtained from 14 of the 18 MDR strains isolated in the survey.
DRb: 5'ccgagaggggacggaaac-3'. The amplified biotinylated products were hybridised to a set of 43 oligonucleotides covalently bound to the spoligo-membrane (Isogen Biosciences B.V., Marseen, The Netherlands). Each of these oligonucleotides represented a known spacer sequence within the DR locus. DNAs from M. tuberculosis type isolate $\mathrm{H} 37 \mathrm{Rv}$ and M.bovis BCG, as well as sterile water, were used as controls. The hybridised PCR products were incubated with streptavidin-peroxidase conjugate and the membrane was then exposed to the chemiluminescence system (Amersham, Little Chalfont, England) followed by exposure to X-ray film (Hyperfilm ECL, Amersham), according to the manufacturer's instructions. The X-ray film was developed using standard photochemical procedures after two hours of exposure. The films were scanned and analysed using Bionumerics program, version 4.0 (Applied Maths, Kourtrijk, Belgium).

\section{RFLP analysis of IS6 I I0}

RFLP analysis was carried out using Southern blot transfer and DNA hybridisation with IS6110 according to the internationally standarised methodology [9]. Briefly, chromosomal DNA extracted by the CTAB method and digested with PvuII was separated by electrophoresis in an agarose gel. After electrophoresis, restriction fragments were blotted onto nylon membrane using a vacuum blotter and hybridised with a peroxidase-labelled 867-bp IS6110-specific sequence. M. tuberculosis strain 14323 was used as a marker to allow comparison of the IS6110 patterns. The ECL Direct Labelling and Detection System (Amersham Biosciencies) was used for probe labelling and detection of hybridisation signals. The films (Hyperfilm ECL; Amersham) were scanned and the patterns compared.

\section{Molecular characterisation of drug resistance}

A point mutation in codon 315 of the catalase-peroxidase gene (katG) linked to INH-resistance were detected as described by Uhl et al. [37], and any mutations within an 81-bp fragment of the $r p o B$ gene for RIF resistance were investigated. Between 10 and $100 \mathrm{ng}$ of DNA was added to a reaction tube containing a PCR mixture: $50 \mathrm{mM} \mathrm{KCl}$, $10 \mathrm{mM}$ Tris- $\mathrm{HCl}, 1.5 \mathrm{mM} \mathrm{MgCl}_{2}, 200 \mu \mathrm{M}$ [each] deoxynucleoside triphosphate, $2.5 \mathrm{U}$ of Taq polymerase (pure Re Taq $^{\mathrm{TM}}$ Ready-To Go ${ }^{\mathrm{TM}}$ [PCR] Beads- Amersham, Biosciences), sterile deionised water and $2.5 \mu \mathrm{M}$ of each primer.

A 620-bp portion of the kat $G$ gene was amplified with primers KatG 904: 5'-agctcgtatggcaccggaac-3' and KatG 523: 5 '-ttgacctcccacccgacttg-3', and the resulting product was digested with MspI (Boehring Mannheim). After separation in a 3\% agarose gel, the fragments were visualised by ethidium bromide staining and exposure to UV light. 
The $r p o B$ gene was amplified with primers rpoB1: 5'-tacggtcggcgagctgatcc-3' and rpoB2: 5'-tacggcgttcgatgaacc, yielding a $432 \mathrm{bp}$ fragment containing the hot-spot region. PCR products were purified with a commercial kit (ExoSAP-IT-USB Corporation). After sequencing (Servicio de Secuenciación de DNA-CNIO. Madrid, Spain) BLASTn software was used for DNA sequence comparisons [38].

\section{Computer analysis}

The patterns obtained by the different methods were compared. The dendrograms were constructed using the unweighted-pair group method using average linkages (UPGMA) after pairwise comparison of strains by calculating the Dice coefficient. Optimisation was set at $1 \%$ and position tolerance at $1.5 \%$.

The spoligotyping results were entered in a binary format ( 1 and 0 ) according to the hybridisation results (positive or negative, respectively) as Excel (Microsoft, CA) spreadsheets and compared to the updated international spoligotyping database of the Pasteur Institute of Guadeloupe [19]. Only patterns with $100 \%$ similarity were considered as clusters. At the time of the study, the updated SpolDB4 contained 29,363 patterns distributed into 1689 SITs and 2,860 orphan patterns consisting of entries occurring only once in the database (SIT is defined as an identical spoligotype in two or more isolates). Some of the patterns were included in the clades or families already described $[14,20]$. A cluster of $M$. tuberculosis was defined as two or more isolates with identical spoligotyping or IS6110 RFLP patterns.

\section{Phylogeny reconstruction}

Biolayout software using parsimony principles [22] was used to construct a genetic network of spoligotypes found in Venezuela. In the model shown in Figure 2, each arrow represents a likely evolutionary link between two spoligotypes differing by a single genetic change, whether by loss of a single or of many direct variable repeats (DVRs), and the size of the circles indicating the spoligotypes is proportional to the number of isolates in the cluster.

\section{Authors' contributions}

LA conceived the study, carried out the molecular genetic studies, analysed the data and drafted the manuscript; RA, $\mathrm{ME}, \mathrm{AG}$ and AVdeS participated in the design and carried out the first survey of anti-tuberculosis drug-resistance, analysed the data, and provided the clinical isolates for molecular study. CR and JR carried out mycobacteriological diagnostics, isolation of clinical isolates, identification, drug susceptibility tests and provided information about the clinical isolates; CL participated in the genotyping studies; AC assisted with data entry, conducted the bioinformatics programming and statistical analysis; MAL and MJR provided technical help in the conservation of the strains; CS and NR carried out the phylogeny reconstruction studies, participated in the identification and designation of the SITs and also helped draft the manuscript; CM participated in the design of the study, and provided critical comments for the manuscript; SS conceived the study, and participated in its design, coordination of the investigation, and helped to draft the manuscript for consideration for publication. All authors contributed to the study, read and approved the final manuscript.

\section{Acknowledgements}

We acknowledge to the personnel of the 23 Regional Team attached to the National Program of Tuberculosis and the National Tuberculosis Reference Laboratory, Venezuela, whose high quality of service and cooperation have made this work possible.

This work was supported in part by the Spanish "Fondo de Investigación Sanitaria" (FIS 03/0743, FIS 0I/3088). Liselotte Aristimuño performed this work as part of her doctoral thesis with a doctoral fellowship of the Universidad Centroccidental Lisandro Alvarado, Venezuela.

\section{References}

I. WHO: Global tuberculosis control: surveillance, planning, financing. WHO report 2006. WHO/HTM/TB/2006.362. Geneva; World Health Organization; 2006.

2. Valladares R: Desarrollo de la Lucha. Antituberculosa en Venezuela. Informe y Análisis hasta 1959. In Revista Venezolana de Sanidad y Asistencia Social. $N^{\circ}$ Volume XXV. Caracas. Venezuela; 1960:2-3.

3. Ministerio de Salud y Desarrollo Social: Evaluación del Programa Nacional de Control de la Tuberculosis. In Reporte Anual Caracas. Venezuela; 2003.

4. Ministerio de Salud y Desarrollo Social: Evaluación del Programa Nacional de Control de la Tuberculosis. In Seminario Técnico Administrativo Caracas. Venezuela; 2000.

5. WHO/IUATLD: TB-MDR Surveillance Report, Anti-tuberculosis Drug Resistance in the World. Report $\mathbf{N}^{\circ} 3$. In WHO/ HTM/TB/2004.343 Geneva; World Health Organization; 2004.

6. European Concerted Action on New Generation Genetic Markers and techniques for the Epidemiology and Control of Tuberculosis: Beijing/W genotype Mycobacterium tuberculosis and drug resistance. Emerg Infect Dis 2006, I 2:736-743.

7. Caminero JA, Pena J, Campos-Herrero MI, Rodríguez JC, García I, Cabrera P, Lafoz C, Damper S, Takiff H, Afonso O, Pavon JM, Torres MJ, van Soolingen D, Enarson A, Martin C: Epidemiological evidence of the spread of a Mycobacterium tuberculosis strain of the Beijing genotype on Gran Canaria Island. Am J Respir Crit Care Med 200I, 164: I 165-II70.

8. García de Viedma D, Chaves F, Iñigo J: New Route of importation of Mycobacterium tuberculosis Beijing genotype. Emerg Infect Dis 2006, I 2(I): 169-170.

9. van Embden JDA, Cave MD, Crawford JT, Dale JW, Eisenach KD, Gicquel B, Hermans P, Martin C, McAdam R, Shinnick TM, Small PM: Strain identification of Mycobacterium tuberculosis by DNA fingerprinting: recommendations for a standardized methodology. J Clin Microbiol 1993, 31:406-409.

10. van Soolingen $D$ : Molecular epidemiology of tuberculosis and other mycobacterial infections: main methodologies and achievments. Journal of Internal Medicine 200I, 249: I-26.

II. Kamerbeek J, Schouls L, Kolk A, van Agterveld M, van Soolingen D, Kuijper S, Bunschoten A, Molhuizen H, Shaw R, Goyal M, van Embden JDA: Simultaneous detection and strain differentiation of Mycobacterium tuberculosis for diagnosis and epidemiology. J Clin Microbiol 1997, 35:907-9|4.

12. Kremer K, van Soolingen D, Frothingham R, Haas WH, Martin C, Palittapongarnpim P, Plikayitys BB, Riley LW, Yakrus MA, Musser JM, van Embden JDA: Comparison of methods based on different molecular epidemiological markers for typing of Mycobacterium tuberculosis complex strains: interlaboratory study of 
discriminatory power and reproducibility. J Clin Microbiol 1999 , 37:2607-26I8

13. Sebban M, Mokrousov I, Rastogi N, Sola C: A data-mining approach to spacer oligonucleotide typing of Mycobacterium tuberculosis. Bioinformatics 2002, 18:235-243.

14. Sola C, Filliol I, Gutiérrez C, Mokrousov I, Vincent V, Rastogi N: Spoligotype database of Mycobacterium tuberculosis : Biogeographical distribution of shared types and epidemiological and phylogenetic perspectives. Emerg Inf Dis 200I, 7:390-396.

15. Bifani PJ, Plikaytis BB, Kapur V, Stockbauer K, Pan X, Lutfey ML, Moghazeh SL, Eisner W, Daniel TM, Kaplan MH, Crawford JT, Musser JM, Kreiswirth BN: Origin and interstate spread of a New York City multidrug-resistant Mycobacterium tuberculosis clone family. JAMA 1996, 275:452-457.

16. de C Ramos M, Soini H, Roscanni GC, Jacques M, Villares MC, Musser JM: Extensive cross-contamination of specimens with Mycobacterium tuberculosis in a reference laboratory. I Clin Microbio 1999, 37:916-919.

17. Jaureguy F, Gutierrez MC, Marie CJ, Poirier C, Panseuriu S, Pascal J, Valeyre D, Picard B, Vincent V, Deny P: Epidemiological survey of a suspected nosocomial case of tuberculosis by spoligotyping. Pathologie Biologie 2005, 53:48|-484.

18. Sola C, Filliol I, Legrand E, Mokrousov I, Rastogi N: Mycobacterium tuberculosis phylogeny reconstruction based on combined numerical analysis with ISI08I, IS6IIIO, VNTR, and DRbased spoligotyping suggests the existence of two new phylogeographical clades. J Mol Evol 200I, 53:680-689.

19. Spol DB4 [http://www.pasteur-guadeloupe.fr/tb/bd myco.html]

20. Filliol I, Driscoll JR, van Soolingen D, Kreiswirth BN, Kremer K, Valtudie G, Anh DD, Barlow R, Banerjee D, Bifani PJ, Brudey K, Cataldi A, Cooksey RC, Cousins DV, Dale JW, Dellagostin OA, Drobniewski F, Engelmann G, Ferdinand S, Gascoyne-Binzi D, Gordon M, Gutierrez MC, Haas W, Heersma H, Kassa-Kelembho E, Ho ML, Makristathis A, Mammina C, Martin G, Mostrom P, Mokrousov I, Narbonne V, Narvskaya O, Nastasi A, Ngo Niobe-Eyangoh SN, Pape JW, RasolofoRazanamparany V, Ridell M, Rossetti ML, Stauffer F, Suffys PN, Takiff $\mathrm{H}$, Texier-Maugein J, Vincent V, de Waard J, Sola C, Rastogi N: Snapshot of moving and expanding clones of Mycobacterium tuberculosis and their global distribution assessed by spoligotyping in an International study Global distribution of Mycobacterium tuberculosis spoligotypes. J Clin Microbiol 2003, 41:1963-1970

2I. Brudey K, Driscoll JR, Rigouts L, Prodinger WM, Gori A, AI-Hajoj SA Allix C, Aristimuño L, Arora J, Baumanis V, Binder L, Cafrune P. Cataldi A, Cheong S, Diel R, Ellermeier C, Evans JT, Fauville-Dufaux M, Ferdinand S, Garcia de Viedma D, Garzelli C, Gazzola L, Gomes HM, Gutierrez MC, Hawkey PM, Van Helden PD, Kadival GV, Kreiswirth BN, Kremer K, Kubin M, Kulkarni SP, Liens B, Lillebaek T, Ly HM, Martin C, Martin C, Mokrousov I, Narvskaia O, Ngeow YF, Naumann L, Niemann S, Parwati I, Rahim MZ, Rasolofo-Razanamparany V, Rasolonavalona T, Rossetti ML, Rusch-Gerdes S, Sajduda A, Samper S, Shemyakin I, Singh UB, Somoskovi A, Skuce R, van Soolingen D, Streicher EM, Suffys PN, Tortoli E, Tracevska T, Vincent V, Victor TC Warren R, Yap SF, Zaman K, Portaels F, Rastogi N, Sola C: Mycobacterium tuberculosis complex genetic diversity: mining the fourth international spoligotyping database (SpolDB4) for classification, population and epidemiology. BMC Microbiol 2006, 6(I):23.

22. Enright A], Ouzounis CA: BioLayout an automatic graph layout algorithm for similarity visualization. Bioinformatics 200I, I 7(9):853-854.

23. Duchene V, Ferdinand S, Filliol I, Gugan JF, Rastogi N, Sola C: Phylogenetic reconstruction of the Mycobacterium tuberculosis complex within four settings of the Caribbean region: tree comparative analysis and first appraisal on their phylogeography. Infect Gen Evol 2004, 4:5-I4.

24. Brudey K, Filliol I, Ferdinand S, Guernier V, Duval P, Maubert B, Sola $C$, Rastogi N: Long-term population-based genotyping study of Mycobacterium tuberculosis complex isolates in the French departments of the Americas. J Clin Microbiol 2006, 44:|83-19|.

25. Escalante P, Ramaswamy S, Sanabria H, Soini H, Pan X, Valiente-Castillo O, Musser JM: Genotypic characterization of drug-resistant Mycobacterium tuberculosis isolates from Peru. Tub and Lung Dis 1998, 79: III-118.

26. Torres MJ, Criado A, Gonzalez N, Palomares JC, Aznar J: Rifampin and Isoniazid resistance associated mutations in Mycobacte- rium tuberculosis clinical isolates in Seville, Spain. Int J Tuberc Lung Dis 2004, 6:160-163.

27. Jou R, Chen HY, Chiang CY, Yu MC, Su IJ: Genetic diversity of multidrug-resistant Mycobacterium tuberculosis isolates and identification of I I novel rpoB alleles in Taiwan. J Clin Microbiol 2005, 43: 1390-1394.

28. Heep M, Brandstatter B, Rieger U, Lehn N, Richter E, Rusch-Gerdes $S$, Niemann S: Frequency of rpoB mutation inside and outside the cluster I region in rifampin-resistant clinical Mycobacterium tuberculosis isolates. J Clin Microbiol 200 I, 39: I07-I I0.

29. Sajduda A, Brzostek, Poplawaka M, Kopec EA, Zwolska, Niemann S, Dziadek J, Hillemann D: Molecular characterization of Rifampin and Isoniazid resistant Mycobacterium tuberculosis strains isolated in Poland. J Clin Microbiol 2004, 42:2425-243I.

30. Telenti A, Imboden P, Marchesi F, Lowrie D, Cole S, Colston MJ, Matter L, Schopfer K, Bodmer T: Detection of rifampicin-resistance mutations in Mycobacterium tuberculosis. Lancet 1993, 341:647-650.

3I. Samper S, Iglesias MJ, Rabanaque MJ, Gómez LI, Lafoz MC, Jimenez MS, Ortega A, Lezcano MA, Van Soolingen D, Martin C, The Spanish working group on MDR-TB: Systematic molecular characterization of Multidrug-Resistant Mycobacterium tuberculosis complex isolates from Spain. J Clin Microbiol 2005, 43: I220-I 227.

32. Ying Z, Vilchez C, Jacobs W: Mechanisms of drug resistance in Mycobacterium tuberculosis. In Tuberculosis and the Tubercle Bacillus Volume 8. Edited by: Stewart T Cole. Washington, D.C: ASM Press; 2005:115-133

33. Ramaswamy SV, Dou SJ, Rendon A, Yang Z, Cave MD, Graviss EA: Genotypic analysis of multidrug-resistant Mycobacterium tuberculosis isolates from Monterrey, Mexico. J Clin Microbiol 2004, 53:107-113.

34. Hofling CC, Pavan EM, Giampaglia CM, Ferrazoli L, Aily DC, de Albuquerque DM, Ramos MC: Prevalence of katG Ser3 15 substitution and rpoB mutations in isoniazid-resistant Mycobacterium tuberculosis isolates from Brazil. Int J Tuberc Lung Dis 2005, 9:87-93.

35. Canetti G, Fox W, Khomenko A, Mahler HT, Menon NK, Mitchison DA, Rist N, Smelev NA: Advances in techniques of testing mycobacterial drug sensitivity and the use of sensitivity tests in tuberculosis control programmes. Bull World Health Organization 1969, 41:21-43.

36. Siddiqui SH, Libonati JP, and Middlebrook: Evaluation of a rapid radiometric method for drug susceptibility testing of $\mathrm{Myco}$ bacterium tuberculosis. J Clin Microbiol I 198I, I3:908-9 I2.

37. Uhl JR, Sandhu GS, Kline BC, Cockerill FR III: PCR-RFLP detection of point mutations in the catalase-peroxidase gene (katG) of M. tuberculosis associated with isoniazid resistance. In PCR protocols for emerging infectious diseases Edited by: Persing DH. Washington, D.C: ASM Press; 1996: I 44-196.

38. TubercuList World-Wide Web Server [http://genolist.pas teur.fr/TubercuList/]
Publish with Biomed Central and every scientist can read your work free of charge

"BioMed Central will be the most significant development for disseminating the results of biomedical research in our lifetime. "

Sir Paul Nurse, Cancer Research UK

Your research papers will be:

- available free of charge to the entire biomedical community

- peer reviewed and published immediately upon acceptance

- cited in PubMed and archived on PubMed Central

- yours - you keep the copyright
BioMedcentral 